\title{
Sistem Pendeteksi Kualitas Daging Dengan Ekualisasi Histogram Dan Thresholding Berbasis Android
}

\author{
Anggit Sri Herlambang ${ }^{1)}$, Oky Dwi Nurhayati ${ }^{2)}$, Kurniawan Teguh Martono ${ }^{2)}$ \\ Program Studi Sistem Komputer, Fakultas Teknik, Universitas Diponegoro \\ Jalan Prof. Sudharto, Tembalang, Semarang, Indonesia
}

\begin{abstract}
Abstrak - Kebutuhan daging sapi yang meningkat sering dimanfaatkan oleh penjual daging sapi untuk melakukan kecurangan. Kecurangan yang sering dimanfaatkan biasanya dalam hal kualitas daging sapi. Kualitas daging ditentukan oleh beberapa parameter, termasuk parameter ukuran, tekstur, karakteristik warna, bau daging dan lain - lain. Parameter adalah salah satu faktor penting untuk menentukan kualitas daging. Umumnya dalam menentukan kualitas daging dilakukan dengan menggunakan indra penglihatan. Sehingga cara manual masih bersifat subjektif dalam menilai kualitas daging. Penelitian ini bertujuan untuk merancang aplikasi sistem pendeteksi kualitas daging dengan sampel 20 citra daging data uji.

Sistem pendeteksi kualitas daging dengan ekualisasi histogram dan thresholding berbasis android ini dibangun dengan menggunakan bahasa pemrograman berbasis Android yang terintegrasi dengan SDK Android, Eclipse dan library OpenCV. Metode yang digunakan menggunakan metode pra-pengolahan ekualisasi histogram dan segmentasi thresholding pengolahan citra. Deteksi kualitas daging dilakukan dengan mencari nilai statistik ekstraksi ciri citra berdasarkan data citra daging dari penelitian.

Hasil penelitian ini adalah dapat menentukan nilai statistik mean dan standar deviasi dari hasil citra olahan ekualisasi histogram dan thresholding disertai analisis kualitas citra daging sapi. Pengujian black box dari aplikasi sistem pendeteksi kualitas daging ini menunjukkan bahwa semua fungsi yang terdapat pada aplikasi ini telah berhasil berjalan sesuai fungsinya. Penelitian ini harapannya bisa digunakan untuk membantu penelitian tahap selanjutnya.
\end{abstract}

Kata Kunci : Ekualisasi Histogram, Thresholding, Ekstraksi Ciri, Android, OpenCV, Eclipse.

\section{PENDAhUluan}

$\mathrm{D}$ aging merupakan salah satu komoditi peternakan yang menjadi andalan yang sangat menunjang untuk memenuhi kebutuhan dasar bahan pangan di Indonesia. Kebutuhan akan bahan pangan berupa daging khususnya daging sapi semakin hari semakin meningkat dikarenakan meningkatnya kesadaran manusia akan pentingnya kebutuhan gizi. Daging sapi memiliki banyak sekali kandungan yang bermanfaat bagi manusia. Salah satu kandungan gizi dalam daging sapi yang sangat bermanfaat bagi tubuh manusia adalah protein. Konsumsi daging sapi di Indonesia terus mengalami peningkatan., sehingga dimanfaatkan oleh pihak tertentu untuk meraup keuntungan banyak dengan melakukan kecurangan dalam penjualan daging sapi. Tentu saja penjualan daging dengan kualitas rendah maupun yang tidak layak konsumsi dapat merugikan konsumen tanpa memikirkan akibat yang ditimbulkan akibat kecurangan tersebut. ${ }^{[1]}$

Masyarakat membutuhkan pengetahuan yang cukup untuk dapat membedakan daging sapi yang layak konsumsi atau tidak. Perlunya pihak-pihak tertentu memberikan penyuluhan kepada masyarakat agar dapat memiliki pengetahuan yang cukup mengenai kualitas daging sapi. Dalam mencari tahu bagaimana kualitas daging sapi dapat memanfaatkan perangkat komunikasi yang sudah banyak dipakai masyarakat sekarang ini. Salah satunya penggunaan smartphone yang dapat menjalankan berbagai macam aplikasi. Karena dapat menjalankan berbagai macam aplikasi ini, memunculkan ide untuk membuat sebuah aplikasi pengolahan citra digital. Dimana aplikasi ini dapat mendeteksi kualitas daging sapi dari suatu citra daging yang diambil. Aplikasi ini nantinya berbasis android dengan library dari OpenCV serta menggunakan Eclipse dengan menggunakan metode ekualisasi histogram dan segmentasi thresholding. OpenCV merupakan sebuah library perangkat lunak yang ditujukan untuk pengolahan citra dinamis secara real-time yang bisa dimasukkan sebagai library Android karena aplikasi ini termasuk aplikasi pengolahan citra. Eclipse sendiri digunakan untuk mengembangkan perangkat lunak, salah satunya berbasis android dimana sistem operasi ini sedang menjadi tren di masyarakat. Ekualisasi histogram memiliki kelebihan dapat melakukan transformasi terhadap histogram citra asli sedemikian sehingga didapat histogram citra hasil dengan distribusi lebih seragam. 
Sedangkan thresholding merupakan salah satu metode segmentasi yang paling sederhana sehingga mudah diterapkan yaitu pengambangan mensegmentasikan citra menjadi dua wilayah.

Tujuan dari tugas akhir ini adalah untuk membuat aplikasi pengolahan citra dengan metode ekualisasi histogram dan segmentasi thresholding, mencari nilai statistik mean dan standar deviasi ekstraksi ciri citra dari citra daging yang diolah kemudian menampilkan hasil analisis citra daging kategori daging baik atau tidak layak konsumsi. Untuk menghindari pembahasan yang meluas maka dalam tugas akhir ini ditetapkan batasan-batasan masalah dengan hal-hal sebagai berikut :

1. Pengujian dilakukan pada daging sapi yang diambil dengan kamera 4 MP dan 5 MP dengan jarak $20 \mathrm{~cm}$ dan $30 \mathrm{~cm}$.

2. Pembuatan aplikasi yang dapat mendeteksi kualitas dari citra daging dengan metode pra-pengolahan ekualisasi histogram dengan segmentasi thresholding.

3. Perancangan dan pembuatan aplikasi menggunakan editor Eclipse Luna yang dijalankan dari sistem operasi windows 8.1 dan library OpenCV 2.4.9

4. Aplikasi diimplementasikan dalam smartphone sistem operasi android versi Jelly Bean 4.3 hingga versi Lollipop 5.1

5. Aplikasi dibuat untuk penelitian dan tidak dipublikasikan secara meluas.

6. Penelitian dilakukan pada 20 sampel data citra daging sapi yang didapat dari penelitian sebelumnya.

\section{DASAR TEORI}

\section{A. Pengolahan Citra Digital}

Secara harfiah citra (image) adalah gambar pada bidang dua dimensi. Ditinjau dari sudut pandang matematis, citra merupakan fungsi terus menerus (continue) dari intensitas cahaya pada bidang dua dimensi. Sumber cahaya menerangi objek, objek memantulkan kembali sebagian dari berkas cahaya tersebut. Pantulan cahaya ini ditangkap oleh oleh alat-alat optik, sehingga bayangan objek yang disebut citra tersebut terekam. Citra digital merupakan suatu matriks yang terdiri dari baris dan kolom, dimana setiap pasangan indeks baris dan kolom menyatakan suatu titik pada citra. Nilai matriksnya menyatakan nilai kecerahan titik tersebut. Titik-titik tersebut dinamakan sebagai elemen citra atau pixel. Pengolahan citra adalah pemrosesan citra, khususnya dengan menggunakan komputer, menjadi citra yang kualitasnya lebih baik. Pengolahan Citra bertujuan memperbaiki kualitas citra agar mudah diinterpretasi oleh manusia atau mesin. Teknik-teknik pengolahan citra mentransformasikan citra menjadi citra lain. Jadi, masukannya adalah citra dan keluarannya juga citra, namun citra keluaran mempunyai kualitas lebih baik daripada citra masukan. ${ }^{[2]}$

\section{B. Daging Sapi}

Daging adalah bahan pangan yang sangat dibutuhkan tubuh, dimana dalam daging terkandung banyak gizi serta dalam daging memiliki mutu protein yang tinggi, hal ini dikarenakan pada daging terdapat kandungan asam amino esensial lengkap dan seimbang. Daging juga didefinisikan sebagai otot yang melekat pada kerangka. Menurut Pamungkas (2012) protein yang terdapat pada daging lebih mudah dicerna oleh pencernaan daripada protein yang berasal dari nabati. Tidak hanya itu, bahan pangan ini juga memiliki beberapa jenis vitamin dan mineral. Daging sapi berdasarkan SNI adalah bagian otot skeletal dari karkas sapi yang aman, layak dan lazim dikonsumsi oleh manusia dapat berupa daging segar, daging segar dingin, atau daging beku. Karkas sapi adalah bagian dari tubuh sapi sehat yang telah disembelih secara halal, telah dikuliti, dikeluarkan jerohan, dipisahkan kepala dan kaki mulai dari tarsus atau karpus ke bawah, organ reproduksi dn ambing, ekor, serta lemak yang berlebih. ${ }^{[3]}$

\section{Ekualisasi Histogram}

Menurut Sianipar (2013), histogram adalah suatu grafik yang mengindikasikan jumlah kemunculan setiap level keabuan pada suatu citra. Menurut Gonzales et al (2003) ekualisasi histogram merupakan metode untuk memperbaiki kualitas citra dengan cara mengubah sebaran tingkat keabuan citra. Hal ini dimaksudkan agar sebaran tingkat keabuan lebih merata dibandingkan dengan citra aslinya. Menurut Sianipar (2013) masalah yang terjadi pada pelebaran histogram adalah fakta bahwa diperlukannya masukan dari pengguna atau pemakai. Seringkali dijumpai bahwa pendekatan yang lebih baik adalah menggunakan ekualissi histogram karena keseluruhan prosedur dilakukan secara otomatis. Idenya adalah mengubah histogram suatu citra menjadi seragam; yaitu setiap grafik batang pada histogram harus sama tinggi, atau dengan kata lain bahwa setiap level keabuan dalam citra harus memiliki frekuensi kemunculan yang sama. $^{[2]}$

\section{Thresholding}

Thresholding merupakan salah satu metode segmentasi yang sederhana sehingga mudah diterapkan yaitu pengambangan mensegmentasikan citra menjadi dua wilayah. Thresholding digunakan untuk mengatur jumlah derajat keabuan yang ada pada citra. Dengan menggunakan thresholding maka derajat keabuan bisa diubah sesuai keinginan, misalkan diinginkan menggunakan derajat keabuan 8, maka tinggal membagi nilai derajat keabuan dengan 8. Proses thresholding ini pada dasarnya adalah proses pengubahan kuantisasi pada citra. Untuk mencoba melakukan proses thresholding, perlu dibuat program untuk dapat mengubah-ubah nilai tresholding sesuai keinginan. Sehingga perlu ditampilkan dua citra, yaitu citra asli (gray-scale) dan hasil thresholdingnya dengan nilai thresholding yang ditentukan melalui input. Thresholding atau pengambangan merupakan metode yang bisa digunakan dalam segmentasi dalam pengolahan citra digital atau bisa juga pemisahan antara derau dalam pengolahan isyarat 1 dimensi atau juga 2 dimensi. ${ }^{[4]}$ 


\section{E. Android}

Android adalah sistem operasi untuk telepon seluler yang berbasiskan Linux. Android menyediakan platform terbuka bagi para pengembang untuk menciptakan aplikasi mereka sendiri sehingga dapat digunakan oleh bermacammacam peranti bergerak. Yang dibutuhkan untuk memulai pemrograman Android adalah Android SDK (Software Development Kit) dan juga JDK (Java Development Kit) serta membutuhkan Java IDE yang digunakan untuk menuliskan coding Android, dan juga Emulator untuk menjalankan aplikasi yang telah dibuat. ${ }^{[5]}$

\section{F. Eclipse Luna}

Eclipse Luna merupakan salah satu versi dari sebuah IDE (Integrated Development Environment) untuk mengembangkan perangkat lunak dan dapat dijalankan di semua platform (platform-independent). Eclipse pada saat ini merupakan salah satu IDE favorit dikarenakan gratis dan open source, yang berarti setiap orang boleh melihat kode pemrograman perangkat lunak ini. Selain itu, kelebihan dari Eclipse yang membuatnya populer adalah kemampuannya untuk dapat dikembangkan oleh pengguna dengan komponen yang dinamakan plug-in. Eclipse pada dasarnya merupakan sebuah kernel, yang mengangkat plug-in. Apa yang dapat digunakan di dalam Eclipse sebenarnya adalah fungsi dari plug-in yang sudah diinstal. Secara standar Eclipse selalu dilengkapi dengan JDT (Java Development Tools), plug-in yang membuat Eclipse kompatibel untuk mengembangkan 24 program Java, dan PDE (Plug-in Development Environment) untuk mengembangkan plug-in baru. Eclipse beserta plug-in-nya diimplementasikan dalam bahasa pemrograman Java. Konsep Eclipse adalah IDE yang terbuka (open), mudah diperluas (extensible) untuk apa saja, dan tidak untuk sesuatu yang spesifik. Eclipse tidak saja untuk mengembangkan program Java, akan tetapi dapat digunakan untuk berbagai macam keperluan, cukup dengan menginstal plug-in yang dibutuhkan. Apabila ingin mengembangkan program $\mathrm{C} / \mathrm{C}++$ terdapat plug-in $\mathrm{CDT}$ $(\mathrm{C} / \mathrm{C}++$ Development Tools $)$. Selain itu, pengembangan secara visual bukan hal yang tidak mungkin oleh Eclipse, plug-in UML2 tersedia untuk membuat Diagram UML. Dengan menggunakan PDE setiap orang bisa membuat plugin sesuai dengan keinginannya. ${ }^{[6]}$

\section{G. OpenCV}

Open CV (Open Computer Vision) adalah sebuah API Library yang sudah sangat familiar pada Pengolahan Citra Computer Vision. Computer Vision itu sendiri adalah salah satu cabang dari Bidang Ilmu Pengolahan Citra (Image Processing) yang memungkinkan komputer dapat melihat seperti manusia. Dengan vision tersebut komputer dapat mengambil keputusan, melakukan aksi, dan mengenali terhadap suatu objek. Beberapa pengimplementasian dari Computer Vision adalah Face Recognition, Face Detection, Face/Object Tracking, Road Tracking, dan lainlain. OpenCV adalah sebuah API yang dikembangkan oleh perusahaan Intel. Device yang telah menggunakan API ini salah satunya Kinect Xbox. OpenCV adalah library open source untuk computer vision untuk $\mathrm{C} / \mathrm{C}++$, OpenCV didesain untuk aplikasi real-time, memiliki fungsi - fungsi akuisisi yang baik untuk image atau video. ${ }^{[7]}$

\section{H. Ekstraksi Ciri}

Ekstraksi ciri adalah proses mengambil ciri-ciri yang terdapat pada objek didalam citra untuk mengenali objek tersebut. Ekstraksi ciri merupakan langkah awal dalam melakukan klasifikasi dan interpretasi citra. Proses ini berkaitan dengan kuantisasi karakteristik citra ke dalam sekelompok nilai ciri yang sesuai. Ciri-ciri umum yang digunakan untuk mengenali satu atau beberapa objek didalam citra adalah ukuran, posisi atau lokasi, dan orientasi atau sudut kemiringan objek terhadap garis acuan yang digunakan. Salah satu metode yang digunakan pada ekstraksi ciri adalah ekstraksi ciri statistik orde pertama. ${ }^{[15]}$ Ekstraksi ciri orde pertama merupakan metode pengambilan ciri yang didasarka pada karakteristik histogram citra. Histogram menunjukkan probabilitas kemunculan nilai derajat keabuan piksel pada suatu citra. Dari nilai-nilai pada histogram yang dihasilkan, dapat dihitung beberapa parameter ciri statistik orde pertama dalam penelitian ini antara lain adalah rata-rata (mean) dan standar deviasi.

\section{Mean $(\mu)$}

Menunjukkan ukuran dispersi dari suatu citra seperti persamaan (1).

$$
\mu=\sum_{n} f_{n} p\left(f_{n}\right)
$$

Dimana $f_{n}$ merupakan suatu nilai intensitas keabuan, sementara $p\left(f_{n}\right)$ menunjukkan nilai histogramnya (probabilitas kemunculan intensitas tersebut pada citra). ${ }^{[8]}$

\section{Standar Deviasi $(\sigma)$}

Standar Deviasi adalah akar kuadrat dari total selisih dengan nilai rata-ratanya. Standar Deviasi adalah salah satu teknik statistik yang digunakan untuk menjelaskan homogenitas kelompok. Standar Deviasi merupakan variasi sebaran data, semakin kecil sebarannya berarti variasi nilai data makin sama. akan didapat jumlah ukuran yang detail Dengan menghitung nilai standar deviasi dari sebuah citra, sub band. rumus standar deviasi (persamaan 2.8)..$^{[1]}$

$$
\sigma=\overline{\frac{1}{N} N_{l=1} X_{l}-\mu^{2}}
$$

Dimana $N$ merupakam jumlah total piksel, $X_{i}$ menunjukkan nilai piksel pada posisi ke-I dan $\mu$ merupakan nilai rata-rata piksel dalam citra.

\section{Perancangan Sistem}

Perancangan sistem aplikasi perangkat bergerak dibutuhkan tahap prosedur pengembangan perangkat lunak. Berikut adalah tahap-tahap perancangan diagram alir pada sistem pendeteksi kualitas daging dengan metode ekualisasi histogram dan thresholding berbasis android.

A. Kebutuhan Sistem

1. Perangkat Lunak

- $\quad$ Sistem Operasi Microsoft Windows 8.1 Pro 64-bit.

- Eclipse Luna.

- OpenCV. 
- $\quad$ Microsoft Office Word 2013

- $\quad$ Sistem Operasi Android OS, v5.1 (Lollipop).

- $\quad$ Fiji ImageJ.

2. Perangkat Keras

- $\quad$ Laptop ASUS N46VM, Prosesor Intel® Core TM i73610QM CPU @ 2.30GHz (8 CPUs), 2.3GHz, dan RAM 8 GB.

- $\quad$ Smartphone Oneplus One 5.5 inch.

\section{B. Prosedur Pengembangan Program}

Pada tahap ini dalam melakukan perancangan program terdapat perancangan diagram alir. Berikut ini perancangan diagram alir pada perangkat lunak:

1. Perancangan Diagram Alir Sistem

Perancangan sistem aplikasi perangkat bergerak dibutuhkan tahap prosedur pengembangan perangkat lunak. Tahap ini sangat penting untuk menentukan setiap proses berjalannya aplikasi yang akan dibuat. Tahap-tahap dapat dilakukan dengan menggunakan diagram alir. Diagram alir perancangan sistem ditunjukkan pada gambar 1.

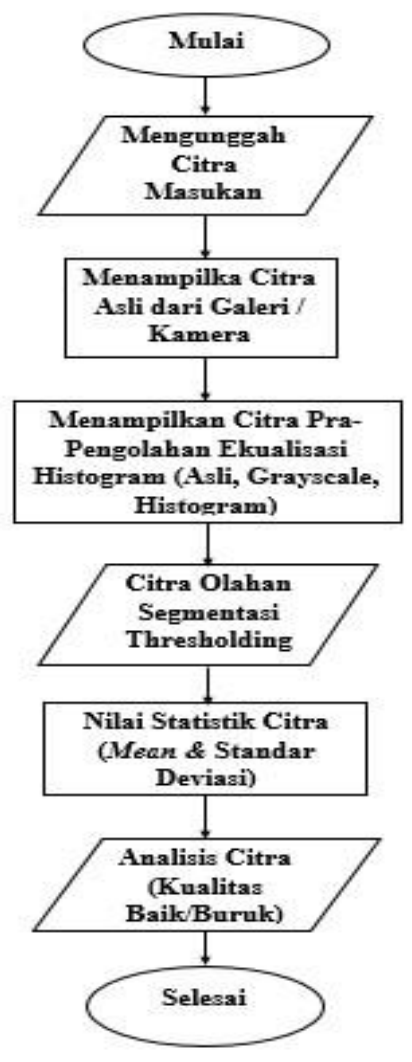

Gambar 1 Diagram alir sistem

2. Perancangan Diagram Alir Aplikasi

Pada diagram alir yang dirancang merupakan proses algoritma didalam aplikasi pendeteksi kualitas daging dari awal hingga sistem selesai. Selanjutnya adalah diagram perancangan diagram alir aplikasi yang ditunjukkan pada gambar 2.

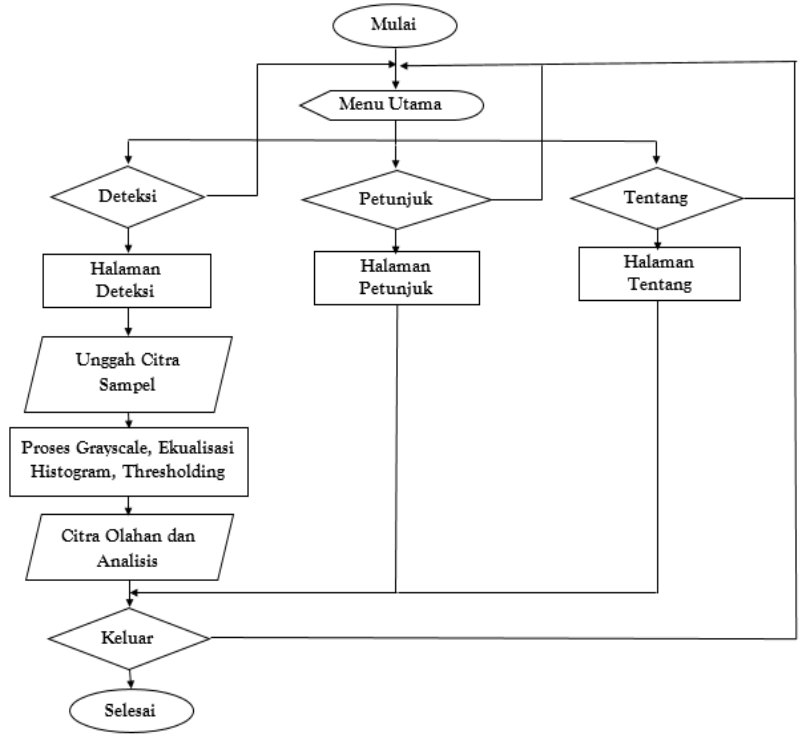

Gambar 2 Diagram alir aplikasi

Aktivitas dalam diagram alir yang sirancang merupakan aktivitas dari aplikasi pada saat digunakan oleh pengguna dari tampilan saat dibuka hingga tampilan akhir.

C. Perancangan Antarmuka Perangkat Lunak

Rancangan antarmuka atau tampilan aplikasi yang akan dibuat harus dapat memberikan gambaran dan penjelasan dari setiap button, teks dan gambar dari aplikasi. Rancangan tampilan ini menggambarkan keterkaitan setiap halaman dan juga menjelaskan arah komunikasi pada aplikasi. Berikut ini perancangan antarmuka perangkat lunak:

- $\quad$ Antarmuka Halaman Menu Utama

Halaman ini menunjukkan rancangan tampilan menu utama ditunjukkan pada gambar 3 .

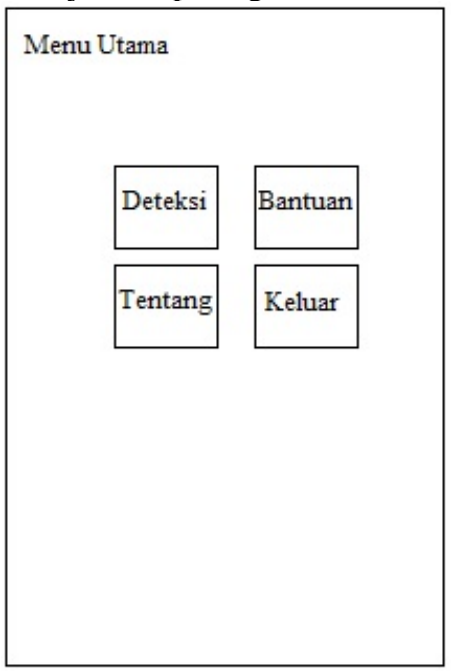

Gambar 3 Halaman Menu Utama

3. Antarmuka Halaman Unggah Citra

Halaman ini menunjukkan rancangan tampilan unggah citra yang ditunjukkan pada gambar 4 . 


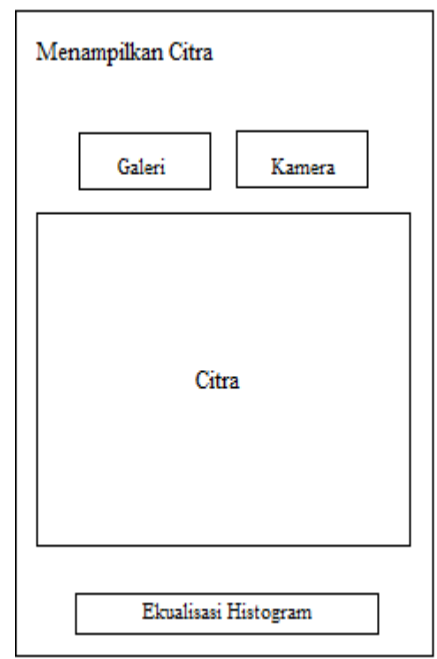

Gambar 4 Form Unggah Citra

4. Antarmuka Halaman Pra-Pengolahan

Halaman ini menunjukkan rancangan tampilan prapengolahan yang terdiri dari citra asli, citra aras keabuan (grayscale) dan citra ekualisasi histogram yang ditunjukkan pada gambar 5 .

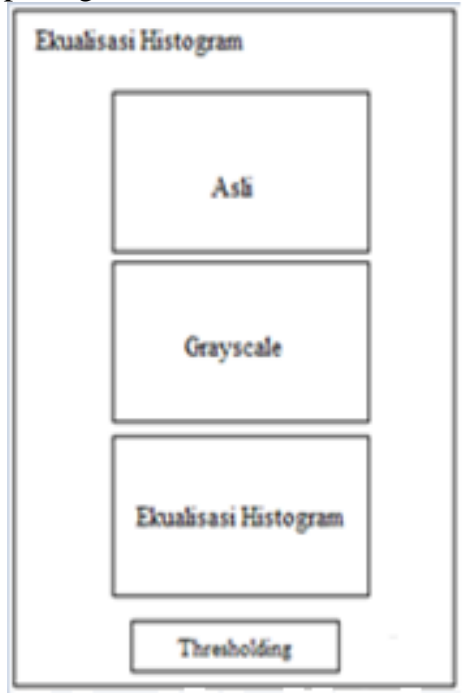

Gambar 5 Halaman Pra-Pengolahan

5. Antarmuka Halaman Citra Olahan

Halaman ini menunjukkan rancangan tampilan citra olahan yang ditunjukkan pada gambar 6 .

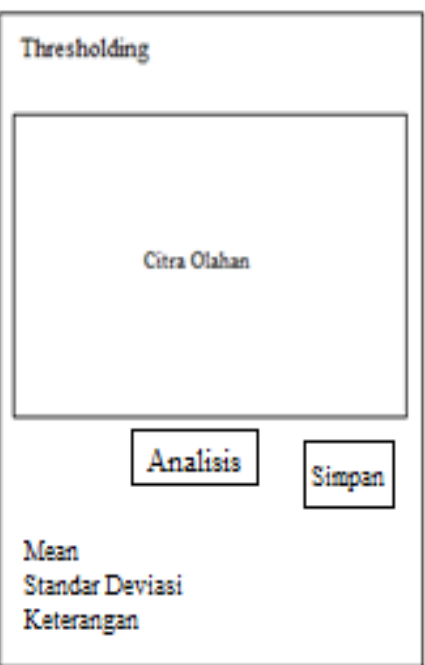

Gambar 6 Halaman Citra Olahan

6. Antarmuka Halaman Petunjuk

Halaman ini menunjukkan rancangan tampilan tentang yang ditunjukkan pada gambar 7 .

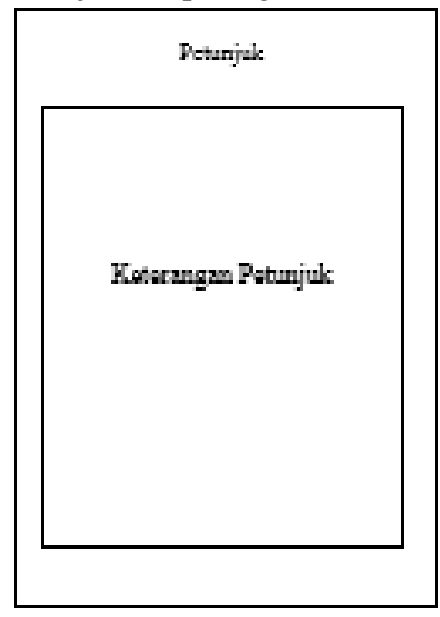

Gambar 7 Halaman Petunjuk

7. Antarmuka Halaman Tentang

Halaman ini menunjukkan rancangan tampilan tentang yang ditunjukkan pada gambar 8 .

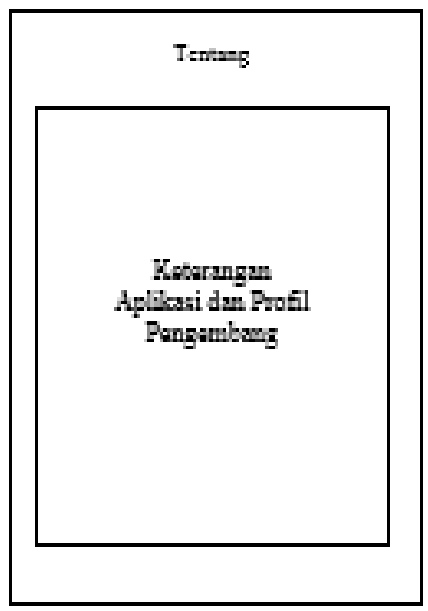

Gambar 8 Halaman Tentang 


\section{IMPLEMENTASI DAN PENGUJIAN}

A. Implementasi Antarmuka Aplikasi

1. Halaman Menu Utama

Merupakan halaman awal mulai ketika aplikasi mulai dijalankan. Tampilan ditunjukkan pada gambar 9 .

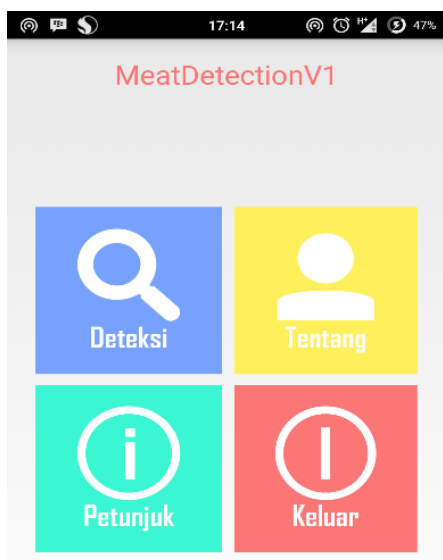

Gambar 9 Halaman menu utama

\section{Halaman Unggah Citra}

Merupakan halaman yang terdiri dari 3 tombol yaitu galeri, kamera dan pra pengolahan. Tampilan ditunjukkan pada gambar 10

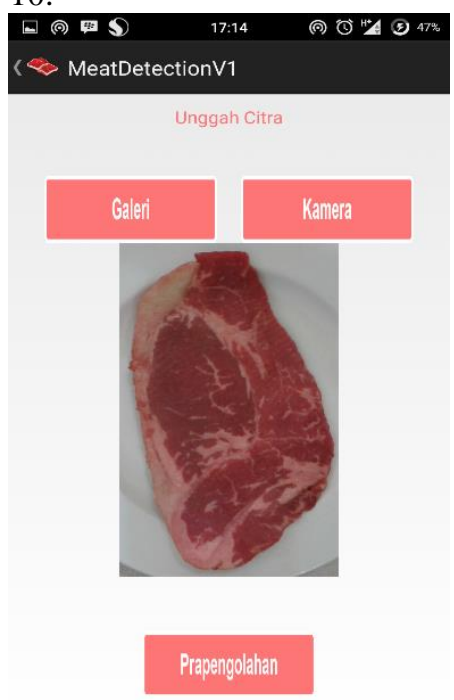

Gambar 24 Halaman Unggah Citra

3. Halaman Pra Pengolahan

Merupakan halaman yang terdiri dari 3 tampilan gambar yaitu citra asli, citra grayscale, citra ekualisasi dan tombol segmentasi. Tampilan ditunjukkan pada gambar 11 .

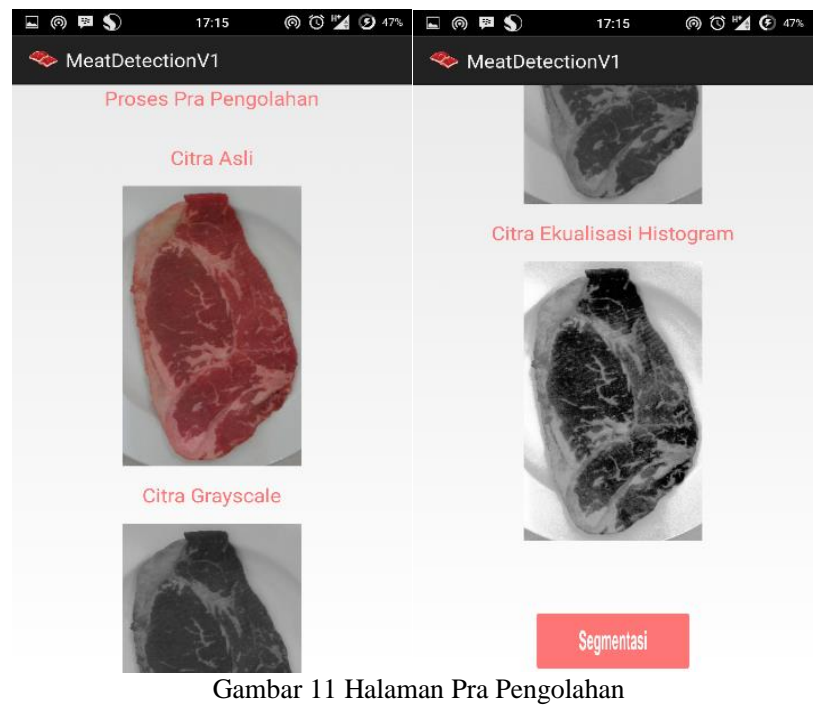

4. Halaman Hasil Olahan \& Analisis

Merupakan halaman yang terdiri dari tampilan gambar dan tombol analisis. Tampilan ditunjukkan pada gambar 12 .
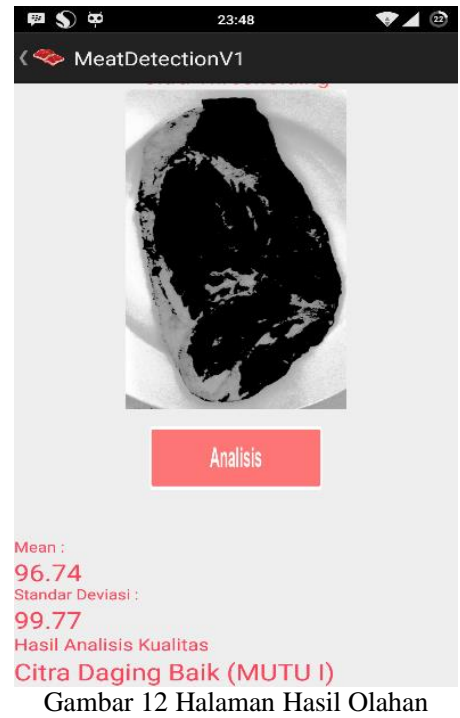

5. Halaman Petunjuk

Merupakan halaman petunjuk penggunaan aplikasi. Tampilan ditunjukkan pada gambar 13.

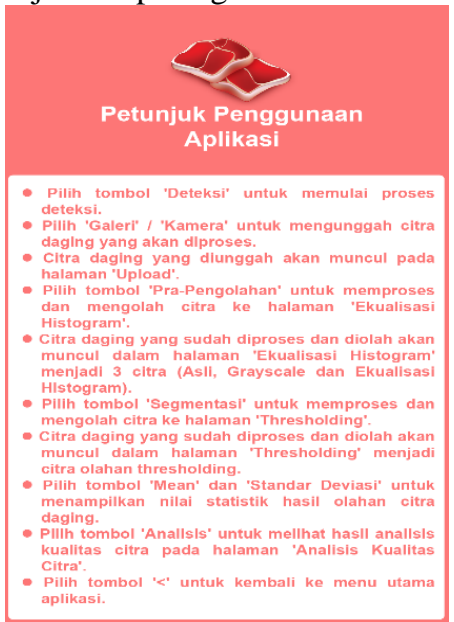

Gambar 13 Halaman Petunjuk 
6. Halaman Tentang

Merupakan halaman profil dari pengembang dan versi aplikasi. Tampilan ditunjukkan pada gambar 14 .

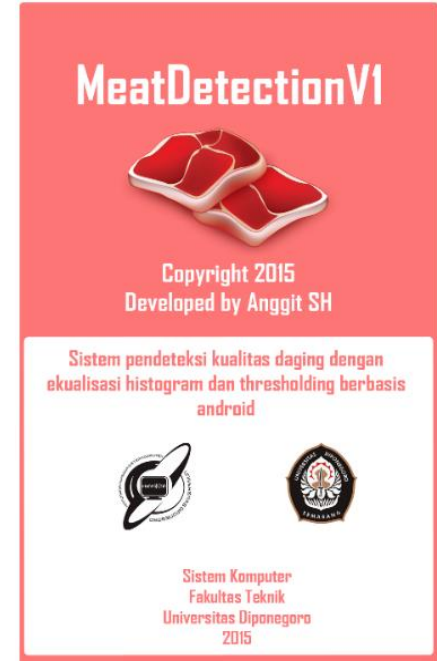

Gambar 14 Halaman Tentang

\section{B. Hasil Penelitian}

Dalam penelitian ini tahap pengujian sistem akan dilakukan dengan melakukan pengujian terhadap beberapa citra yang sudah dikumpulkan berdasarkan kriteria baik dan buruk dengan ekstensi .jpg dimana telah diambil 20 sampel data citra daging sapi yang dipilih untuk pengujian sistem yang akan digunakan sebagai parameter. Citra daging sapi dengan format jpeg dikonversi menjadi citra grayscale (aras keabuan), selanjutnya citra dikonversi ke citra grayscale (aras keabuan) ekualisasi histogram sebagai pra pengolahan citra untuk meningkatkan akurasi ketepatan dari sampel citra daging sapi. Terakhir citra dikonversi ke segmentasi citra thresholding.

\section{Hasil Olahan Citra Masukan} berikut :

Hasil olahan citra masukan dapat dijelaskan sebagai

Citra Asli

Citra asli dimuat sebagai masukan program dengan format citra RGB 24 bit berekstensi .jpg. Citra tersebut ditunjukkan seperti gambar 15 .

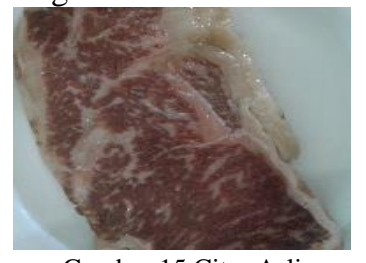

Gambar 15 Citra Asli

- $\quad$ Citra Aras Keabuan (Grayscale)

Citra asli yang dikonversikan menjadi aras keabuan dengan format 8 bit berekstensi .jpg. Citra tersebut ditunjukkan seperti gambar 16.
- $\quad$ Citra Ekualisasi Histogram

Citra aras keabuan dikonversi ke citra ekualisasi histogram 8 bit dengan ekstensi .jpg. Citra tersebut ditunjukkan seperti gambar 17.

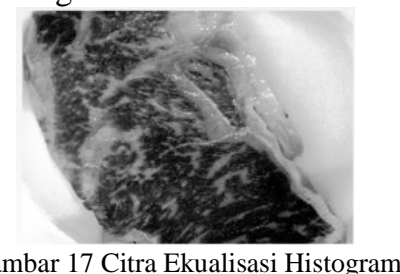

\section{- $\quad$ Citra Thresholding}

Citra ekualisasi histogram yang dikonversi ke segmentasi citra thresholding 8 bit dengan ekstensi .jpg. Citra tersebut ditunjukkan seperti gambar 18.

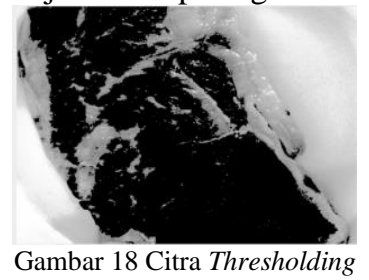

2. Penentuan Parameter Kualitas Citra Daging Sapi - $\quad$ Penentuan Parameter Tahap 1

Penentuan parameter tahap 1 merupakan tahapan untuk menentukan penilaian kualitas daging sapi. Pada tahap ini penilaian kualitas dilakukan secara subjektif dari warna yang dilakukan berdasarkan sumber dari Badan Standardisasi Nasional mengenai mutu karkas dan daging sapi (SNI 3932:2008) ${ }^{[9]}$ Penentuan parameter diukur dari warna daging, warna lemak dan marbling. Terbagi menjadi 3 tingkatan mutu daging yang dapat ditunjukkan pada tabel 1 .

Tabel 1 Tingkatan mutu daging

\begin{tabular}{|c|c|c|c|c|}
\hline \multirow{2}{*}{ No } & \multirow{2}{*}{ Jenis uji } & \multicolumn{3}{|c|}{ Persyaratan mutu } \\
\cline { 3 - 5 } & Warna & I & II & III \\
\hline 1 & daging & $\begin{array}{c}\text { Merang } \\
\text { Skor 1-5 }\end{array}$ & $\begin{array}{c}\text { Merah } \\
\text { Kegelapan } \\
\text { Skor 6-7 }\end{array}$ & $\begin{array}{c}\text { Merah } \\
\text { gelap } \\
\text { Skor 8-9 }\end{array}$ \\
\hline 2 & $\begin{array}{c}\text { Warna } \\
\text { lemak }\end{array}$ & $\begin{array}{c}\text { Putih Skor } \\
1-3\end{array}$ & $\begin{array}{c}\text { Putih } \\
\text { kekuningan } \\
\text { Skor 4 - 6 }\end{array}$ & $\begin{array}{c}\text { Kuning } \\
\text { Skor 7-9 }\end{array}$ \\
\hline 3 & Marbling & Skor 9-12 & Skor 5-8 & Skor 1-4 \\
\hline
\end{tabular}

Penilaian warna daging dilakukan dengan melihat warna permukaan otot mata rusuk dengan bantuan cahaya senter dan mencocokkannya dengan standar warna. Nilai skor warna ditentukan berdasarkan skor standar warna yang paling sesuai dengan warna daging. Standar warna daging terdiri atas 9 skor mulai merah muda hingga merah tua.

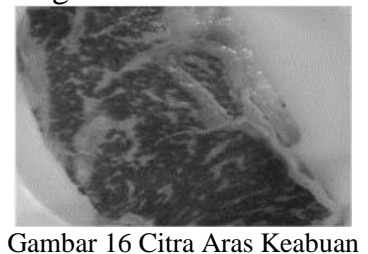




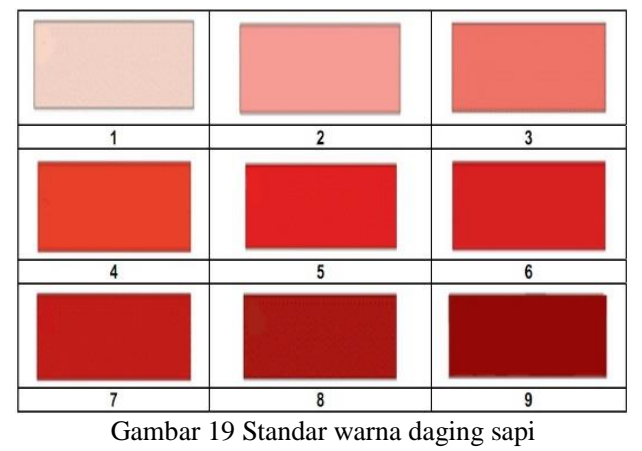

Penilaian warna lemak dilakukan dengan melihat warna lemak subkutis (lapisan terdalam dari kulit) dengan bantuan cahaya senter dan mencocokkannya dengan standar warna. Nilai skor warna ditentukan berdasarkan skor standar warna yang paling sesuai dengan warna lemak. Standar warna lemak terdiri atas 9 skor mulai dari warna putih hingga kuning.

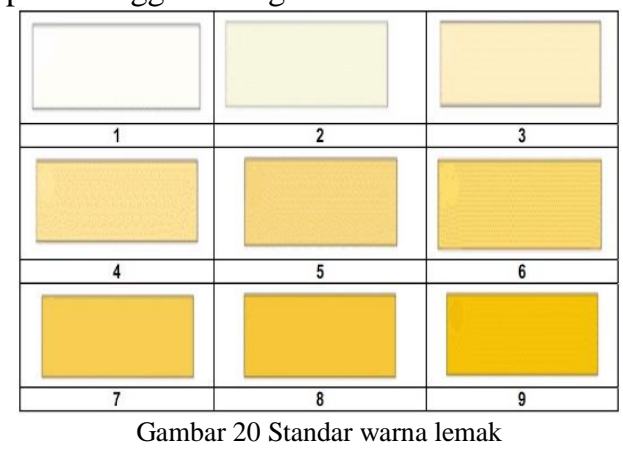

Penilaian marbling dilakukan dengan melihat intensitas marbling pada permukaan otot mata rusuk dengan bantuan cahaya dan mencocokkannya dengan standar marbling. Nilai skor marbling ditentukan berdasarkan skor standar marbling yang paling sesuai dengan intensitas marbling otot mata rusuk. Standar marbling terdiri atas 12 skor mulai dari praktis tidak ada marbling hingga banyak.

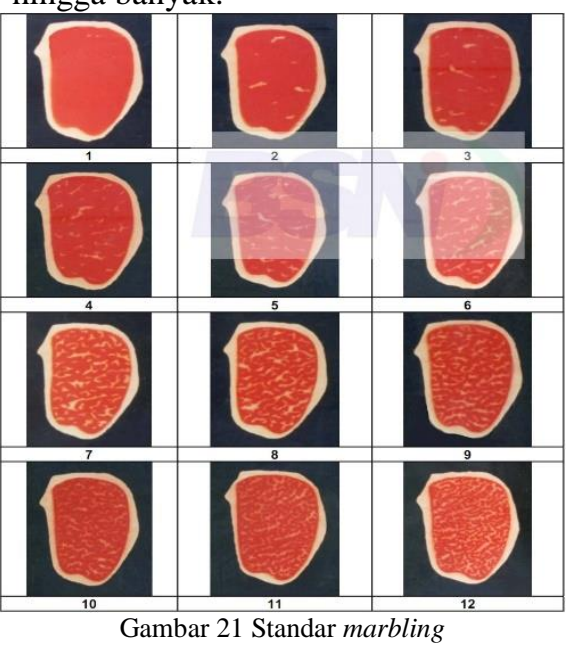

Penentuan Parameter Tahap 2

Penentuan parameter tahap 2 merupakan tahapan untuk menerapkan parameter kualitas daging yang sudah didapat dari tahap 1. Penentuan dilakukan pada 20 sampel data citra yang sudah dipilih sebelumnya secara acak. ${ }^{[10]}$
Sampel-sampel tersebut ditentukan berdasarkan warna daging, warna lemak dan marbling. Berikut ini contoh sampel data citra dari 20 data citra yang diujikan ditunjukkan pada tabel 2.

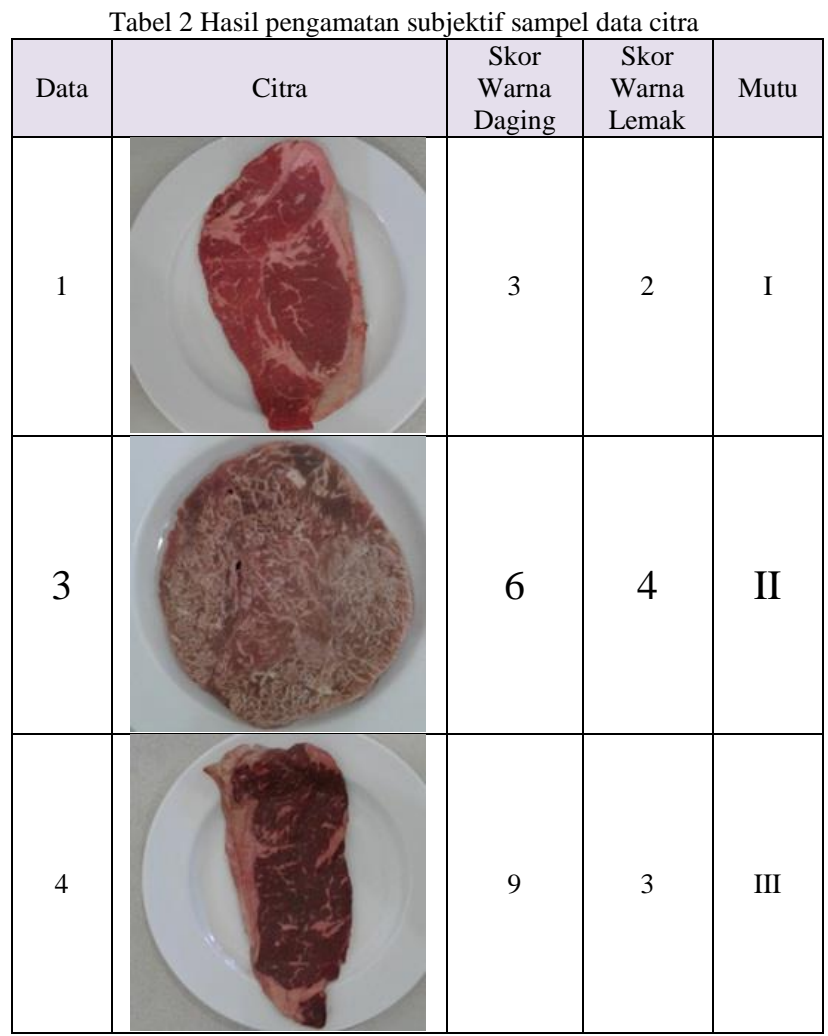

2. Perbandingan Statistik Citra

Merupakan tahapan dalam penelitian setelah menentukan parameter kualitas citra daging. Dalam tahap ini akan dijelaskan mengenai ekstraksi ciri atau analisis citra daging serta membandingkan hasil analisa dengan hasil analisis dari aplikasi pengolahan citra Fiji ImageJ. 20 sampel data citra daging yang sudah ditentukan kualitasnya tersebut masing-masing diproses atau diolah citra, dimana setelah citra terkonversi ke grayscale - ekualisasi histogram - thresholding. Hasil deteksi citra menggunakan Fiji ImageJ ditunjukkan oleh tabel 3.

Tabel 3 Hasil perhitungan ekstraksi ciri citra Fiji ImageJ

\begin{tabular}{|c|c|c|c|c|}
\hline No. & $\begin{array}{l}\text { Citra } \\
\text { Asli }\end{array}$ & $\begin{array}{l}\text { Citra Olahan } \\
\text { (Thresholding) }\end{array}$ & Mean & $\begin{array}{l}\text { Standar } \\
\text { Deviasi }\end{array}$ \\
\hline 1 & & & 141.7 & 126.42 \\
\hline 2 & & & 155.5 & 123.55 \\
\hline
\end{tabular}




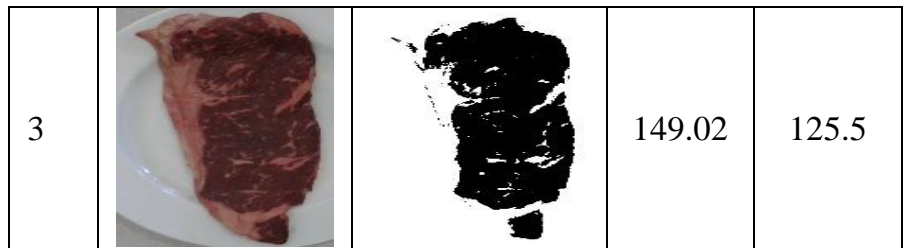

Berikut adalah tabel hasil perhitungan ekstraksi ciri citra "MeatDetectionV1" ditunjukkan oleh tabel 4.

Tabel 4 Hasil perhitungan ekstraksi ciri citra MeatDetectionV1

\begin{tabular}{|c|c|c|c|c|}
\hline No. & $\begin{array}{l}\text { Citra } \\
\text { Asli }\end{array}$ & $\begin{array}{c}\text { Citra } \\
\text { Thresholding }\end{array}$ & Mean & $\begin{array}{l}\text { Standar } \\
\text { Deviasi }\end{array}$ \\
\hline 1 & & & 96.77 & 99.77 \\
\hline 2 & & & 97.04 & 99.22 \\
\hline 3 & & & 96.56 & 99.9 \\
\hline
\end{tabular}

Berdasarkan hasil uji coba menggunakan aplikasi Fiji ImageJ (Tabel 2) dan aplikasi MeatDetectionV1 (Tabel 2) dengan menggunakan proses pengolahan yang sama dapat dihasilkan keluaran nilai statistik yang berbeda. Masing-masing memiliki kelebihan dan kekurangan dalam proses pengukurannya. Faktor-faktor yang mempengaruhi perbedaan ukuran diantaranya adalah hasil dari proses pengolahan citra segmentasi thresholding antara aplikasi Fiji ImageJ dan aplikasi MeatDetectionV1 terlihat citra yang dihasilkan memiliki ketebalan hitam yang berbeda. Pada aplikasi Fiji ImageJ citra yang dihasilkan lebih hitam daripada yang dihasilkan aplikasi MeatDetectionV1. Pada penghitungan nilai statistik di aplikasi Fiji ImageJ, latar belakang tidak ikut dihitung, hanya benar-benar citra dagingnya saja yang dihitung. Sedangkan pada aplikasi MeatDetectionV1, perhitungan nilai statistik yang dilakukan, latar belakang ikut dihitung.

Akurasi ketepatan baca dari masing-masing aplikasi dapat ditunjukkan sebagai berikut.

Aplikasi MeatDetectionV1

Sampel data citra daging di bagi sesuai kualitas mutu yang dihasilkan. Pada setiap kualitas mutu diambil nilai maksimal dan minimal dari perhitungan statistic yang sudah dihasilkan sebelumnya. Dari hasil tersebut didapatkan rentang nilai statistik dari masing-masing kualitas mutu daging yang ditunjukkan pada tabel 5 .
Tabel 1 Rentang Mean dan Standar Deviasi setiap mutu daging

\begin{tabular}{|c|c|c|}
\hline \multirow{2}{*}{$\begin{array}{c}\text { Mutu } \\
\text { Daging }\end{array}$} & \multicolumn{2}{|c|}{ Rentang } \\
\cline { 2 - 3 } & Mean & $\begin{array}{c}\text { Standar } \\
\text { Deviasi }\end{array}$ \\
\hline I & $96.67-96.77$ & $99.77-99.78$ \\
\hline II & $96.78-97.06$ & $99.24-99.76$ \\
\hline III & $96.78<\mathrm{m}$ & $\mathrm{s}<99.24$ \\
$\mathrm{~s}>99.78$
\end{tabular}

Pada hasil penelitian didapatkan 6 (enam) nilai statistik daging yaitu 2 kualitas rata-rata dan 1 kualitas buruk yang menyimpang masuk dalam rentang daging kualitas buruk (Data 5, Data 6 dan Data 11). Penentuan akurasi dapat dihitung.

$$
\begin{aligned}
\text { Akurasi }=100 \% & -\frac{3}{20} * 100 \% \\
= & 100 \%-15 \%=85 \%
\end{aligned}
$$

Akurasi yang dihasilkan menggunakan aplikasi ini memiliki ketepatan baca kualitas daging sebesar $85 \%$.

Aplikasi Fiji ImageJ

Sampel data citra daging di bagi sesuai kualitas mutu yang dihasilkan. Pada setiap kualitas mutu diambil nilai maksimal dan minimal dari perhitungan statistic yang sudah dihasilkan sebelumnya. Dari hasil tersebut didapatkan rentang nilai statistik dari masing-masing kualitas mutu daging yang ditunjukkan pada tabel 6 .

Tabel 2 Rentang Mean dan Standar Deviasi setiap mutu daging

\begin{tabular}{|c|c|c|}
\hline \multirow{2}{*}{$\begin{array}{c}\text { Mutu } \\
\text { Daging }\end{array}$} & Mean & $\begin{array}{c}\text { Standar } \\
\text { Deviasi }\end{array}$ \\
\cline { 2 - 3 } & $141.7-142.26$ & $126.33-126.42$ \\
\hline I & $140.52-141.69$ & $122.36-126.32$ \\
\hline II & $\mathrm{m}<140.52$ & $\mathrm{~s}<122.36$ \\
III & $\mathrm{m}>142.26$ & $\mathrm{~s}>142.26$ \\
\hline
\end{tabular}

Pada hasil penelitian tidak didapatkan nilai yang menyimpang dan masuk dalam rentang daging kualitas mutu lainnya. Penentuan akurasi dapat dihitung.

$$
\begin{aligned}
\text { Akurasi }=100 \% & -\frac{0}{20} * 100 \% \\
= & 100 \%-0 \%=100 \%
\end{aligned}
$$

Akurasi yang dihasilkan menggunakan aplikasi ini memiliki ketepatan baca kualitas daging sebesar $100 \%$.

\section{Pengujian Program}

Pengujian "Sistem Pendeteksi Kualitas Daging dengan Metode Ekualisasi Histogram dan Thresholding Berbasis Android" dilakukan dengan menggunakan pengujian black box yaitu pengujian yang menekankan pada fungsionalitas dari program. Serangkaian pengujian fungsi dari tombol pada program. Tingkat keberhasilan dari pengujian, diukur dengan terpenuhinya spesifikasi kebutuhan program. Hasil dari pengujian fungsi pada program ini, dapat dilihat pada tabel 7. 
Tabel 7 Hasil Pengujian Fungsi Pada Program

\begin{tabular}{|c|c|c|}
\hline No. & Fungsi & Hasil Uji \\
\hline 1 & $\begin{array}{l}\text { Menampilkan halaman Menu } \\
\text { Utama }\end{array}$ & Berhasil \\
\hline 2 & Pemilihan menu Deteksi & Berhasil \\
\hline 3 & $\begin{array}{ll}\text { Menampilkan } & \text { halaman } \\
\text { Mengunggah Citra } & \end{array}$ & Berhasil \\
\hline 4 & $\begin{array}{l}\text { Pemilihan tombol panah }< \\
\text { (halaman Unggah Citra) }\end{array}$ & Berhasil \\
\hline 5 & Pemilihan tombol Galeri & Berhasil \\
\hline 6 & Pemilihan tombol Kamera & Berhasil \\
\hline 7 & $\begin{array}{lll}\text { Pemilihan } & \text { tombol } & \text { Pra- } \\
\text { Pengolahan } & & \\
\end{array}$ & Berhasil \\
\hline 8 & $\begin{array}{l}\text { Menampilkan halaman } \\
\text { Ekualisasi Histogram }\end{array}$ & Berhasil \\
\hline 9 & $\begin{array}{l}\text { Pemilihan tombol < (halaman } \\
\text { Ekualisasi Histogram) }\end{array}$ & Berhasil \\
\hline 10 & Pemilihan tombol Segmentasi & Berhasil \\
\hline 11 & $\begin{array}{l}\text { Menampilkan halaman } \\
\text { Thresholding }\end{array}$ & Berhasil \\
\hline 12 & $\begin{array}{l}\text { Pemilihan tombol < (halaman } \\
\text { Thresholding) }\end{array}$ & Berhasil \\
\hline 13 & Pemilihan tombol Analisis & Berhasil \\
\hline 14 & $\begin{array}{l}\text { Menampilkan Mean, Standar } \\
\text { Deviasi \& Hasil Analisis }\end{array}$ & Berhasil \\
\hline 15 & Pemilihan menu Petunjuk & Berhasil \\
\hline 16 & $\begin{array}{l}\text { Menampilkan halaman } \\
\text { Petunjuk }\end{array}$ & Berhasil \\
\hline 17 & $\begin{array}{l}\text { Pemilihan tombol < (halaman } \\
\text { Petunjuk) }\end{array}$ & Berhasil \\
\hline 18 & Pemilihan menu Tentang & Berhasil \\
\hline 19 & $\begin{array}{l}\text { Menampilkan halaman } \\
\text { Tentang }\end{array}$ & Berhasil \\
\hline 20 & $\begin{array}{l}\text { Pemilihan tombol < (halaman } \\
\text { Tentang) }\end{array}$ & Berhasil \\
\hline 21 & Pemilihan menu Keluar & Berhasil \\
\hline
\end{tabular}

\section{PENUTUP}

\section{A. Kesimpulan}

Berdasarkan hasil pengujian dan analisis pembuatan aplikasi dapat disimpulkan sebagai berikut :

1. Aplikasi yang dibuat pada tugas akhir ini dapat mengolah citra dari sampel data citra atau gambar yang berasal dari galeri smartphone menggunakan proses pengolahan citra ekualisasi histogram dan thresholding.

2. Segmentasi thresholding secara signifikan dapat digunakan untuk mengetahui kualitas daging sehingga dapat digunakan untuk mengidentifikasi.

3. Penentuan Parameter kualitas berhasil menentukan citra dengan kualitas daging baik, rata-rata dan buruk dibuat berdasarkan pendekatan warna daging, warna lemak dan marbling daging sapi.

4. Hasil perbandingan antara aplikasi MeatDetectionV1 dengan aplikasi Fiji atau ImageJ ditentukan berdasarkan nilai statistik mean dan standar deviasi.

5. Perhitungan yang didapatkan aplikasi MeatDetectionV1 berbasis Android memiliki akurasi ketepatan baca kualitas daging lebih kecil sebesar $85 \%$ dari akurasi ketepatan baca kualitas

\section{B. Saran}

daging aplikasi Fiji ImageJ sebesar 100\%.

Berdasarkan pengujian dan analisis terhadap sistem pendeteksi kualitas daging dengan ekualisasi histogram dan thresholding berbasis android, penulis memberikan beberapa saran untuk pengembangan aplikasi dikemudian hari.

1. Penentuan parameter kualitas daging hanya dengan menggunakan pendekatan warna masih kurang akurat. Dibutuhkan cara lain untuk penentuan yang lebih akurat.

2. Memperluas parameter kualitas citra daging lebih dari 3 (tiga) agar pengguna mampu melihat hasil yang lebih spesifik.

3. Perlu perhitungan nilai statistik yang lain untuk mengukur keakuratan aplikasi yang dibangun seperti nilai statistik skewness, kurtosis, dan entropy serta pada nilai statistik orde kedua.

4. Pengembangan aplikasi agar dapat dijalankan pada berbagai platform, seperti iOS, Windows Phone, dan BlackberryPhone, dan Blackberry.

\section{DAFTAR PUSTAKA}

Kiswanto, "Identifikasi Citra Untuk Mengidentifikasi Jenis Daging Sapi Dengan Menggunakan Transformasi Wavelet Haar", Tesis, Universitas Diponegoro, 2012.

[2] Santi, Candra Noor., "Mengubah Citra Berwarna Menjadi Gray-Scale dan Citra Biner”, Skripsi, Unisbank Semarang, 2011.

[3] Wicaksono, Damar., "Perancangan Perangkat Lunak Untuk Analsisi Tingkat Fokus Pada Citra Mikroskop Digital Menggunakan Proses Ekstrasi Ciri”, Skripsi, Universitas Diponegoro, 2013.

[4] Kumaseh, Max R., Latumakulita, Luther dan Nainggolan, Nelson, "Segmentasi Citra Digital Ikan Menggunakan Metode Thresholding”, Jurnal Universitas Sam Ratulangi.

[5] Ardiansyah, F., "Pengenalan Dasar Android". Depok: Biraynara, 2011.

[6] Safaat H, N., "Pemrograman Aplikasi Mobile Smartphone dan Tablet PC”, Bandung: Informatika, 2012.

[7] Bradski, G., \& Kaehler, A. "Learning OpenCV”, Sebastopol, US: O'Reilly Media, Inc, 2008.

[8] O. D. Nurhayati, "Ekstraksi Ciri Citra Termogram Payudara Berbasis Dimensi Fraktal," Disertasi. Jurusan Teknik Elektro Fakultas Teknik Universitas Gajah Mada, Yogyakarta, 2010.

[9] Badan Standardisasi Nasional, "Mutu Karkas dan Daging Sapi”, SNI:3932:2008, 2008.

[10] Adi K., Pujiyanto, S., Nurhayati O. D. and Pamungkas A., "Beef Quality Identification using Color Analysis and K-Nearest Neighbor Classification”, ICICI-BME, Bandung, Indonesia, 2015. 